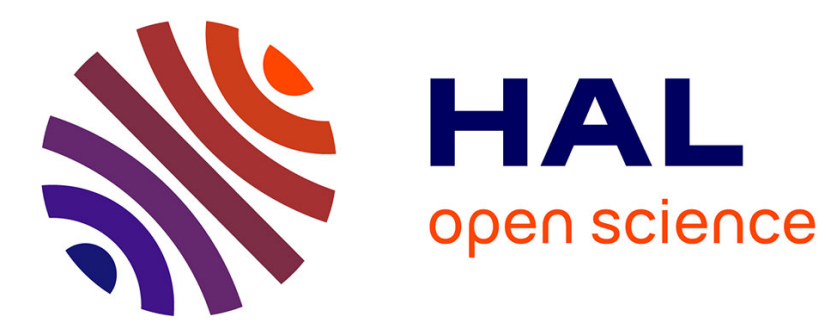

\title{
YAG photoluminescence of GaAs : $\mathrm{Cr}$
}

B. Deveaud, A.M. Hennel, W. Szuszkiewicz, G. Picoli, Gines Martinez Garcia

\section{To cite this version:}

B. Deveaud, A.M. Hennel, W. Szuszkiewicz, G. Picoli, Gines Martinez Garcia. YAG photoluminescence of GaAs: Cr. Revue de Physique Appliquée, 1980, 15 (3), pp.671-674. 10.1051/rphysap:01980001503067100 . jpa-00244773

\section{HAL Id: jpa-00244773 https://hal.science/jpa-00244773}

Submitted on 1 Jan 1980

HAL is a multi-disciplinary open access archive for the deposit and dissemination of scientific research documents, whether they are published or not. The documents may come from teaching and research institutions in France or abroad, or from public or private research centers.
L'archive ouverte pluridisciplinaire HAL, est destinée au dépôt et à la diffusion de documents scientifiques de niveau recherche, publiés ou non, émanant des établissements d'enseignement et de recherche français ou étrangers, des laboratoires publics ou privés. 


\title{
YAG photoluminescence of GaAs : $\mathrm{Cr}\left({ }^{*}\right)$
}

\author{
B. Deveaud $\left({ }^{1}\right)$, A. M. Hennel $\left({ }^{2}\right)\left({ }^{3}\right)$, W. Szuszkiewicz $\left({ }^{2}\right)\left({ }^{3}\right)$, G. Picoli $\left({ }^{1}\right)$ and G. Martinez $\left({ }^{2}\right)$ \\ (1) Centrc National d'Etudes des Télécommunications (CPM/PMT), 22301 Lannion, France. \\ $\left(^{2}\right)$ I niversité Pierre-et-Marie-Curie, Laboratoire de Physique des Solides $\left({ }^{* *}\right)$, 75250 Paris Cedex 05, France. \\ $\left({ }^{3}\right)$ On leave of Institute of Experimental Physics, Warsaw University, 00-681 Warszawa, Poland.
}

\begin{abstract}
Résumé. - Nous avons étudié en photoluminescence une série d'échantillons de GaAs dopés chrome. Deux sources d'excitation ont été utilisées : un laser YAG et un laser krypton. La concentration en porteurs libres des échantillons est comprise entre $10^{18} \mathrm{~cm}^{-3}$ (type $\mathrm{n}$ ) et type $\mathrm{p}$ (faiblement dopé). Trois bandes de photoluminescence sont attribuées au chrome : $0,57 \mathrm{eV}, 0,61 \mathrm{eV}$ et $0,839 \mathrm{eV}$. Nous présentons leurs variations respectives en fonction de la source d'excitation et de la position du niveau de Fermi. Nous proposons un modèle, en termes de coordonnée de configuration, qui pourrait expliquer la plupart des propriétés observées.
\end{abstract}

\begin{abstract}
We have performed photoluminescence experiments, using two excitation sources : a YAG laser and a krypton laser, on a series of Chromium doped GaAs samples. The carrier concentration of the samples ranges from $10^{18}$ (n-type) to p-type (lightly doped). Three bands of photoluminescence at $0.57 \mathrm{eV}, 0.61 \mathrm{eV}$ and $0.839 \mathrm{eV}$ are associated with Chromium. Their respective variations with excitation source and Fermi level position are reported. A tentative explanation in terms of the Configurational-Coordinate model for the $\left(\mathrm{Cr}^{3+}-\mathrm{Cr}^{2+}\right)$ centre is presented.
\end{abstract}

1. Introduction. - Due to the increasing use of chromium-doped semi-insulating substrates of Gallium Arsenide, and due to the problems related to that material (thermal stability [1], Chromium exodiffusion [2]...), a lot of studies have been performed on chromium in $\mathrm{GaAs}$ by different methods. Among these, photoluminescence has been very widely used [3-11] because chromium related photoluminescence is easily observed. The $0.839 \mathrm{eV}$ line has been the subject of a great deal of papers and the outstanding opinion is that this luminescence is due to an internal transition $\left({ }^{5} E_{-}{ }^{5} T_{2}\right)$ of the $\mathrm{Cr}^{2+}$ centre.

Our attempt has been to correlate absorption under hydrostatic pressure, EPR and photoluminescence measurements on a series of chromium doped samples having a varying free carrier concentration. We publish here the results of the photoluminescence experiments and a tentative interpretation of some of the data. Results of other experiments will be published also in this issue [12].

2. Samples. - Two types of samples have been studied. At first, samples doped with chromium during

$\left.{ }^{*}\right)$ Confërence présentée au Congrès de la Socleté Française de Physique (Toulouse).

$\left({ }^{* *}\right)$ Associé au C.N.R.S. the growth process. These samples are semi-insulating with a chromium concentration ranging between a few $10^{15} \mathrm{~cm}^{-3}$ and a few $10^{17} \mathrm{~cm}^{-3}$. They come from different manufacturers : RTC $(80,123$, $217,399,400,420$ ), Sumitomo (FS 20344) and Metal Research. For comparison, semi-insulating samples without chromium have been also tested.

The second kind of samples is obtained by diffusion. Chromium was evaporated on both faces of a slice of n-type GaAs (Te doped $n \sim 10^{18}$ ) and then diffused during one or a few days in a quartz ampulla at different temperatures. For $T<1100^{\circ} \mathrm{C}$, n-type samples of GaAs : Cr were obtained whereas for $T>1100^{\circ} \mathrm{C}$, semi-isolated or p-type samples were obtained. Both faces of the samples are then polished, removing a thickness of about $200 \mu$ from each side. After this treatment, followed by chemical etching, the samples were found optically homogeneous.

3. Experiment. - The photoluminescence set up has the following characteristics. Detection is made using a cooled $\mathrm{PbS}$ cell, the monochromator has a focal length of $1 \mathrm{~m}$ and the sample temperature can be varied between $4 \mathrm{~K}$ and $300 \mathrm{~K}$. We have used two excitation sources : a krypton laser with a power of $1 \mathrm{~W}$ at $0.647 \mu(1.92 \mathrm{eV}$, over-gap excitation) and a YAG laser, $1.5 \mathrm{~W}$ at $1.06 \mu(1.17 \mathrm{eV}$, under-gap excitation). The photoluminescence spectra are cor- 
rected for filter, lens and grating transmission and $\mathrm{PbS}$ cell spectral detectivity.

4. Results. - The results that we obtain depend both on the Fermi-level position in the sample and on the excitation source used. The $0.839 \mathrm{eV}$ band is very easy to recognize due to its zero-phonon line. The identification is far more difficult for the bands appearing in the range 0.5 to $0.7 \mathrm{eV}$. After a fine analysis of all the data it seems to us that four bands exist at $0.57,0.61,0.64$ and $0.68 \mathrm{eV}$, each of them having a width at $4 \mathrm{~K}$ greater than $100 \mathrm{meV}$. Therefore, if two or more of these bands are present in the sample at the same time, we will only see one band of different shape.

In order to analyse the results, we fit the corrected curves with gaussians. This type of fit gives good results except for the $0.57 \mathrm{eV}$ band which is clearly non-symmetrical. In that case. the curve can he correctly fitted, following the Huang-Rhys model [13], by the law

$$
I(h v)=I_{0} \exp (-S) \frac{S\left(\frac{E_{1}-h v}{\hbar \omega}\right)}{\left(\frac{E_{1}-h v}{\hbar \omega}\right) !}
$$

where $E_{\mathrm{t}}$ is the thermal energy of the level, $\hbar \omega$ the energy of the involved phonon and $S$ the mean number of emitted phonons.

Table I summarizes the results of the fit. YES means that we have used the corresponding band to obtain the best fit. It is clear that 3 bands at $0.57,0.61$ and $0.839 \mathrm{eV}$ appear only in Chromium doped samples whereas the two other at 0.64 and $0.68 \mathrm{eV}$ appear also in semi-insulating samples without Chromium.

Table I.

\begin{tabular}{|l|l|l|l|l|l|l|l|}
\hline \multicolumn{1}{|c|}{ Excitation } & \multicolumn{4}{|c|}{ YAG laser } & \multicolumn{3}{c|}{ Krypton laser } \\
\hline Sample & 0.57 & 0.61 & 0.68 & 0.839 & 0.57 & 0.64 & 0.839 \\
\hline $\mathrm{Cr}^{1}: 10^{18} \mathrm{~cm}^{-3}$ & NO & YES & NO & NO & NO & YES & NO \\
\hline $\mathrm{Cr}^{2}: 4 \times 10^{17} \mathrm{~cm}^{-3}$ & NO & YES & NO & NO & YES & YES & YES \\
\hline SI low Cr & YES & NO & NO & NO & YES & YES & YES \\
\hline SI high Cr & YES & NO & NO & YES & Weak & Weak & YES \\
\hline Cr ${ }^{8}:$ p-type & YES & NO & NO & YES & YES & YES & YES \\
\hline SI $:$ no Cr & NO & NO & YES & NO & NO & YES & NO \\
\hline
\end{tabular}

5. Discussion. - The origin of the $0.64 \mathrm{eV}$ (krypton) and $0.68 \mathrm{eV}$ (YAG) bands might be oxygen or some oxygen-induced centre [15] because :

- they appear very strongly in semi-insulating material grown without Chromium but with $\mathrm{Ga}_{2} \mathrm{O}_{3}$ added to the melt,
- their energy correspond quite well to the energy given for the " $\mathrm{O}$ " centre and the Franck-Condon shift that we obtain : $100 \mathrm{meV}$ is close to the shift given by Bois et al. [14].

Unfortunately, it is very difficult to measure chemically the oxygen concentration in GaAs and we have not yet been able to correlate the presence of these levels to the oxygen content of our samples.

We will now associate the three bands $0.57,0.61$ and $0.839 \mathrm{eV}$ to the Chromium doping and discuss their properties. First of all, the $0.839 \mathrm{eV}$ line, has been clearly related to Chromium in a number of papers but :

- The zero-phonon-line structure [9] does not agree with the ground state ${ }^{5} T_{2}$ splitting obtained from EPR measurements.

- In many samples, especially in n-type ones, of $\mathrm{GaAs}: \mathrm{Cr}$, their is no quantitative agreement between the $\mathrm{Cr}^{2+}$ EPR signal and the $0.839 \mathrm{eV}$ luminescence band.

Although this band is clearly an internal transition in some centre, it cannot be related to the ${ }^{5} E_{-}{ }^{5} T_{2}$ transition in $\mathrm{Cr}^{2+}$.

The figure 1 shows the $0.61 \mathrm{eV}$ band. The spectrum from a $n=4 \times 10^{17}$ sample excited by the YAG laser is fitted using the following values :

$$
E_{0}=0.615 \mathrm{eV} \text { and } W=132 \mathrm{meV} .
$$

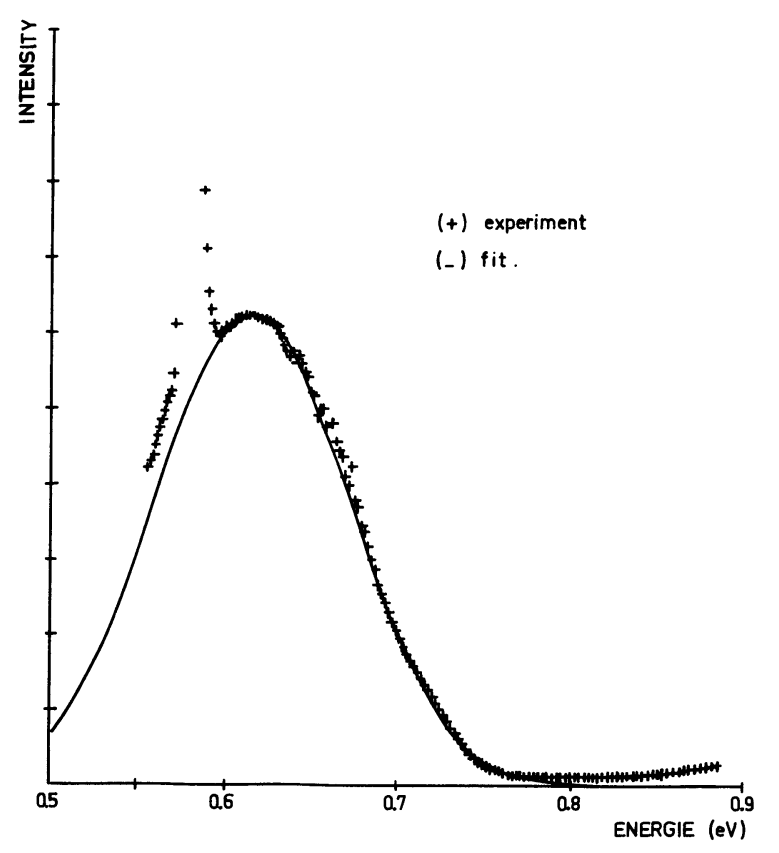

Fig. 1. - Best fit of the spectrum of $\mathrm{Cr}^{2}$ sample $\left(n=4 \times 10^{17} \mathrm{~cm}^{-3}\right)$ excited with a YAG laser. The maximum is at $E_{0}=0.615 \mathrm{eV}$ and the width of the gaussian is $132 \mathrm{meV} .(+)$ : experimental points, (-): theoretical curve.

This band only appears with YAG laser in n-type samples. With krypton light it is hidden by the $0.64 \mathrm{eV}$ band which is much more intense. This band appears 
only on Chromium doped samples and is present in samples where the EPR signal of $\mathrm{Cr}^{2+}$ is stable and the EPR signal of $\mathrm{Cr}^{3+}$ absent.

The $0.57 \mathrm{eV}$ band (Fig. 2) appears with YAG laser in semi-insulating or p-type Chromium doped samples. With krypton laser, this band is weaker and is mixed with the $0.64 \mathrm{eV}$ band but it can be detected in most of the samples. This band exists when $\mathrm{Cr}^{3+}$ (EPR) is present in the sample. It is not symmetrical and it has been fitted, as explained earlier, using the HuangRhys model. The fit cannot give us the 3 parameters $\left(E_{\mathrm{t}}, \hbar \omega, S\right)$ but if we take the Franck-Condon shift $\left(d_{\mathrm{FC}}=S \hbar \omega\right)$ measured by Hennel et al. [12] and Kocot et al. [4] : $170 \mathrm{meV}$, we obtain $E_{\mathrm{t}}=0.72$. If we take the value $E_{\mathrm{t}}=0.76 \mathrm{eV}$ obtained by Hennel et al., we find $d_{\mathrm{FC}}=210 \mathrm{meV}$. The agreement is quite good and we are therefore tentatively propose a configurational coordinate model that could explain some of the properties of Chromium in GaAs.

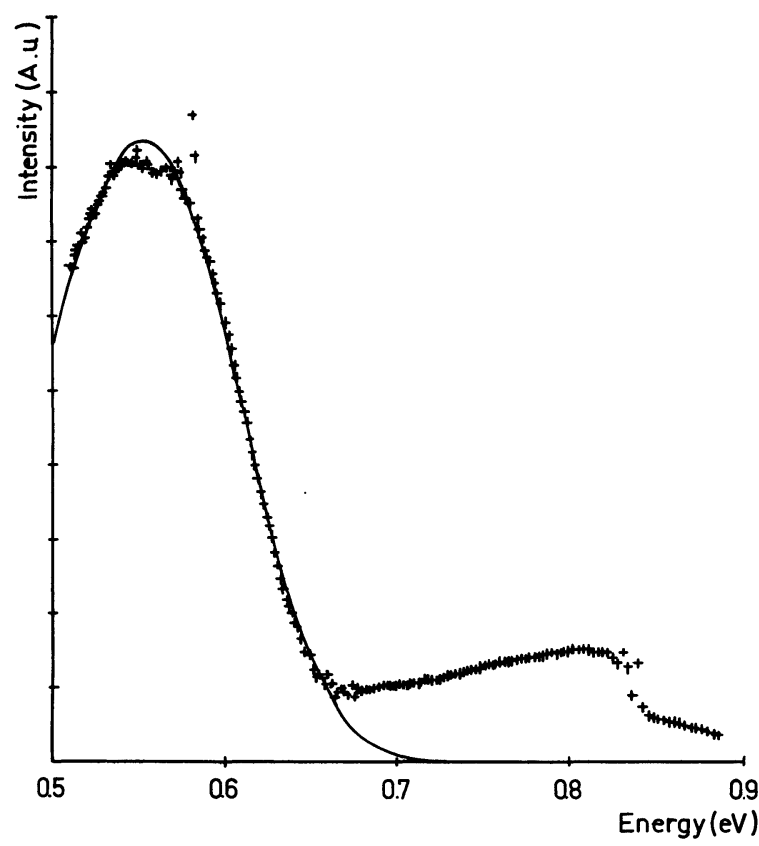

Fig. 2. - Best fit of the $0.57 \mathrm{eV}$ band in SUMITOMO FS 20344 sample. The following parameters have been used (see text) $E_{\mathrm{t}}=0.76 \mathrm{eV}, \hbar \omega=15 \mathrm{meV}, S=14.3\left(d_{\mathrm{FC}}=210 \mathrm{meV}\right) .(+)$ : experimental points, $(-):$ theoretical curve.

The model is shown on figure 3. The $0.57 \mathrm{eV}$ band corresponds to a transition between the $\left(\mathrm{Cr}^{2+}-\mathrm{Cr}^{3+}\right)$ level and the valence band and the $0.61 \mathrm{eV}$ band to a transition between the conduction band and the $\left(\mathrm{Cr}^{2+}-\mathrm{Cr}^{3+}\right)$ level. $\left(\mathrm{Cr}^{2+}-\mathrm{Cr}^{3+}\right)$ means the Chromium acceptor level which is in the state of charge $\mathrm{Cr}^{3+}$ when empty and in the state $\mathrm{Cr}^{2+}$ when filled.

From this model it can easily be explained that the $0.57 \mathrm{eV}$ band is seen with YAG laser when $\mathrm{Cr}^{3+}$ is present in the sample. The absorption of light by the transition Valence-band $\rightarrow \mathrm{Cr}^{2+}$ is very efficient in the energy range of the laser. So we fill the empty places of the centre, and the electrons return to thermal equilibrium by emitting a photon of $0.57 \mathrm{eV}$.

When all $\left(\mathrm{Cr}^{2+}-\mathrm{Cr}^{3+}\right)$ centres are filled, as in n-type samples, we can only make transitions to the conduction band with the laser. The further recombination gives rise to the $0.61 \mathrm{eV}$ band. With krypton laser, the same phenomena occur except that they are masked by the $0.64 \mathrm{eV}$ luminescence.

We can also explain in that model why the internal transition $\left({ }^{5} E-{ }^{5} T_{2}\right)$ in $\mathrm{Cr}^{2+}$ should not be seen. The ${ }^{5} E$ state is degenerated with the conduction band $[16,17]$ and therefore, the transition to the $\mathrm{Cr}^{2+}$ level are more probable from the bottom of the conduction band. The DLTS results [18] are also in reasonable agreement with the thermal values given by our model.

6. Conclusion. - Our experiments suggest that the 0.64 and $0.68 \mathrm{eV}$ bands are not related to Chromium. The $0.839 \mathrm{eV}$ band is related to Chromium, it is an internal transition but it is not the $\left({ }^{5} E-{ }^{5} T_{2}\right)$ transition in $\mathrm{Cr}^{2+}$. The $0.57 \mathrm{eV}$ and $0.61 \mathrm{eV}$ band are the transition between the $\left(\mathrm{Cr}^{2+}-\mathrm{Cr}^{3+}\right)$ level and the valence band and conduction band respectively. The model that we propose agrees quite well with other experiments and it explains why the internal transition $\left({ }^{5} E-{ }^{5} T_{2}\right)$ in $\mathrm{Cr}^{2+}$ was not observed.

Acknowledgments. - We wish to thank M. Poiblaud (RTC-Caen) for providing most of the samples that we have used in this study.

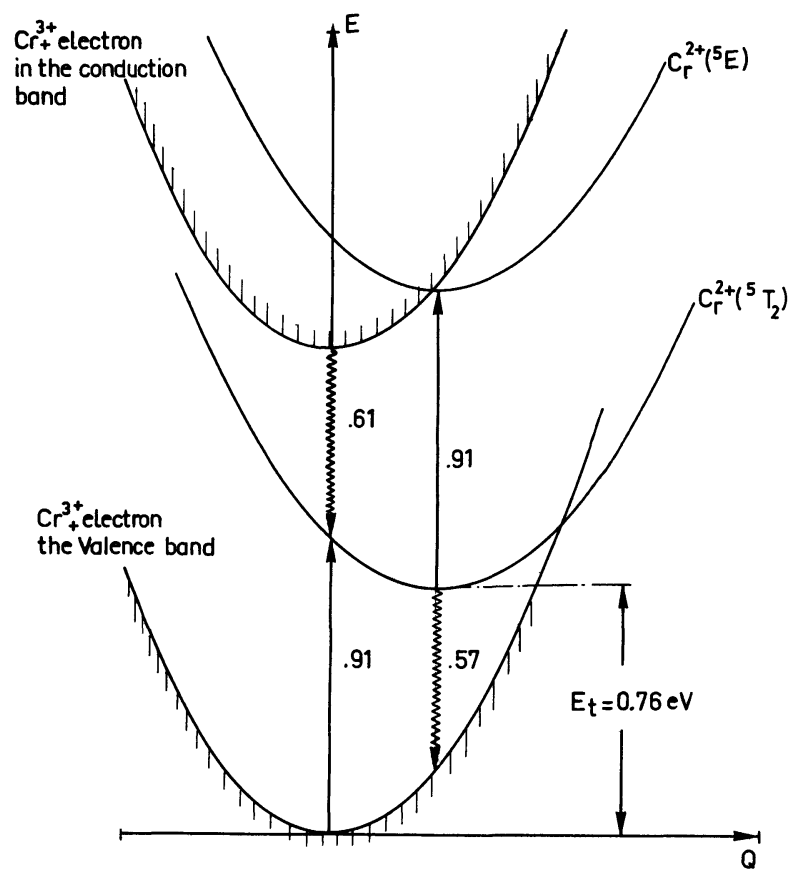

Fig. 3. - Tentative model for the $\left(\mathrm{Cr}^{3+}-\mathrm{Cr}^{2+}\right)$ acceptor centre. The thermal energy of the level with respect to the valence band is $0.76 \mathrm{eV}$. The Franck-Condon shift is $170 \mathrm{meV}$. The absorption and emission energies are indicated. In the $\mathrm{Cr}^{2+}$ charge state, exists an excited level $\left({ }^{5} E\right)$ which is degenerated with the conduction band. 


\section{References}

[1] EISEN, F. H., IBM Conference, Budapest (1978) (to be published).

[2] Huber, A. M., Morillot, G., Linh, N. T., Favennec, P. N., Deveaud, B., Toulouse, B., Appl. Phys. Lett. 34 (1979) 801.

[3] Instone, T., Eaves, L., J. Phys. C 11 (1978) L-771.

[4] Kocot, K., Rao, R. A., Pearson, G. L., Phys. Rev. B 19 (1979) 2059.

[5] Stocker, H. J., Schmidt, M., Proceedings of the Thirteenth International Conference on the Physics of Semiconductors (Tipografia Marves, Rome, 1976) p. 611.

[6] Deveaud, B. and Favennec, P. N., Solid State Commun. 24 (1977) 473.

[7] Koschel, W. H., Bishop, S. G., McCombe, B. D., Solid State Commun. 19 (1976) 521.

[8] SChmidt, M., Stocker, H. J., J. Appl. Phys. 49 (1978) 4438.

[9] Lightowlers, E. C., Henry, M. O., Penchina, C. M., Proceedings of the Fourteenth International Conference on the Physics of Semiconductors Inst. Phys. Conf. Ser. 43 (1979) 307.
[10] Ushakov, V. V., Gippius, A. A., Kornilov, B. V., Sov. Phys. Semicond. 12 (1978) 207.

[11] Batavin, V. V., Popova, G. V., Sov. Phys. Semicond. 8 (1975) 1495.

[12] Hennel, A. M., Szuszkiewicz, W., Martinez, G., ClerJAUD, B., This issue.

[13] CuRIE, D. in Optical properties of ions in solids (di Bartolo edit. Plenum Press) p. 84.

[14] Bois, D., Chantre, A., Vincent, G., Nouailhat, A., Proceedings of the Fourteenth International Conference on the Physics of Semiconductors Inst. Phys. Conf. Ser. 43 (1979) 295.

[15] Deveaud, B., Favennec, P. N., Gallium Arsenide and related compounds Inst. Phys. Conf. Ser. 45 (1979) 492.

[16] Bois, D., Pinard, P., Phys. Rev. B 9 (1974) 4171.

[17] Abagyan, S. A., Ivanov, G. A., KuZnetson, Y. N., Okunev, Y. A., Shanurin, Y. E., Sov. Phys. Semicond. 7 (1974) 989.

[18] Lang, D. V., Logan, R. A., J. Electron. Mater. 4 (1975) 1053. 